\title{
APPLYING PARTICIPATORY OBSERVATION IN ISLAMIC EDUCATION TO IMPROVE STUDENTS' CHARACTER
}

\author{
Ahmad Munjin Nasih \\ Universitas Negeri Malang \\ Jl. Semarang No. 5 Malang, Indonesia, 65145 \\ Email: munjin.nasih.fs@um.ac.id \\ Achmad Sultoni \\ Universitas Negeri Malang \\ Jl. Semarang No. 5 Malang, Indonesia, 65145 \\ Email: achmad.sultoni.fs@um.ac.id \\ Titis Thoriquttyas \\ Universitas Negeri Malang \\ Jl. Semarang No. 5 Malang, Indonesia, 65145 \\ Email: titisthoriq.fs@um.ac.id
}

\section{Achmad Yani}

Sultan Sharif Ali Islamic University

Simpang 347 Jalan Pasar Gadong, Bandar Seri Begawan, Brunei

Email: achmad.yani@unissa.edu.bn

\author{
Supian Ramli \\ Universitas Jambi \\ Jl. Jambi - Muara Bulian Km. 15, Muaro Jambi, Indonesia, 36122 \\ Email: supian.ramli@unja.ac.id
}

\section{Mardan Umar}

Universitas Negeri Manado

Jl. Raya Tondano, Sulawesi Utara, Indonesia, 95618

Email: mardanumar@unima.ac.id

Received: 09, 2020. Accepted: 12, 2020. Published: 12, 2020

\begin{abstract}
This study aims to describe the effectiveness of the Participatory Observation learning model and students' responses to the learning model used in PAI (Pendidikan Agama Islam/Islamic Education). It used qualitative and quantitative methods with a pre-test and post-test nonrandomized group preexperiment design. The 125 participants who were taken from three public universities, were asked to fill out questionnaires and written interviews. The data were analysed using paired t-test and qualitative descriptive analysis. The results showed that first experiment got a $t_{\text {-score }}$ of 6,798 with a significance of 0,$000 ; t_{\text {table }}$ score at 51 degrees of freedom and a significant degree of 0.05 in the form of 2.032. Second experiment obtained a $t_{\text {-score }}$ of 5.991 with a significance of 0.000 ; the $t_{\text {-table }}$ score at 54 degrees of freedom and 0.05 degrees of significance was 2.046. Third experiment achieved a $t$-score of 6.424 with a significance of 0.000 ; the $t_{\text {table }}$ score at 20 degrees of freedom and 0.05 degrees of significance was 2.054 . When compared, $\mathrm{t}_{\text {-score }}>\mathrm{t}_{\text {-table }}$ or significance score $<0.05$, which means that the mean score between pre-test and post-test is significantly different. This means that the Participatory Observation learning model can improve students' religious and social character in learning PAI. This result is in line with the respondents' recognition that they have experienced changes in their character in a positive direction. Students stated that the Participatory Observation learning model was fun and very useful, so that it could be used in PAI learning to improve students' character.
\end{abstract}

Keywords: Islamic Education, Religious Character, Social Character, Teaching Model 


\begin{abstract}
ABSTRAK
Penelitian ini bertujuan mendeskripsikan keefektifan model pembelajaran Observasi Partisipatoris dan respon mahasiswa terhadap model pembelajaran tersebut. Penelitian ini menggunakan metode kualitatif dan kuantitatif dengan desain preeksperimen nonrandomized group pre-test dan post-test. Sumber data adalah 125 mahasiswa dari tiga universitas negeri yang diminta mengisi kuesioner dan wawancara tertulis. Data dianalisis menggunakan t-test berpasangan dan analisis deskriptif kualitatif. Hasil penelitian menunjukkan bahwa eksperimen I mendapatkan t-score 6,798 dengan signifikansi 0,000; skor table pada derajat bebas 51 dan derajat nyata 0,05 berupa 2,032, eksperimen II memperoleh t-score 5,991 dengan signifikansi 0,000; skor table pada derajat bebas 54 dan derajat nyata 0,05 adalah 2,046, and eksperimen III

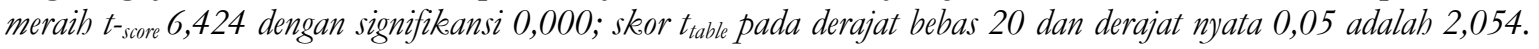
Jika dibandingkan, $t$-score $>t_{\text {table }}$ atau skor signifikansi $<0,05$, bermakna bahwa skor rata-rata antara pre-test dan posttest berbeda secara signifikan. Hal ini berarti model pembelajaran Observasi Partisipatoris dapat meningkatk.an karak.ter religius dan sikap sosial mahasiswa. Hasil ini relevan dengan pengakuan responden bahwa mereka mengalami perubahan karakter ke arah positif. Mahasiswa menyatakan bahwa model pembelajaran Observasi Partisipatoris menyenangkan dan sangat bermanfaat, sehingga dapat digunakan dalam pembelajaran P AI untuk meningkatkan karakter mahasiswa.
\end{abstract}

Kata Kunci: Karakter Religius, Karakter Sosial, Model Pembelajaran, Pendidikan Agama Islam

\title{
INTRODUCTION
}

Based on interviews with some lecturers in three public universities (e.g., State University of Malang, State University of Manado, and Jambi University), it is found that teaching-learning activities of Islamic Education course tends to develop cognitive domain and give less attention towards students' attitude or moral. The tendency towards the cognitive aspect is also apparent in lesson plans and teaching-learning activities. Teaching methods such as lecture, discussion, and presentation are standard in the three universities, with very limited lecturers gave students the duty to do social service to societies around campus.

In the learning assessment aspect, lecturers generally used written questions (objective and subjective), a checklist of presentation performance and al Qur'an reading skills, which are cognitive-based evaluation. Moreover, lecturers rarely implemented an attitude questionnaire, attitude observation, and other instruments to assess the affective domain. As stated by Hidayat, it named such teaching as teaching religion, not teaching how students should live the religion (Hidayat, 1999). The result of teaching is that students increase their knowledge of Islam, but student's faith and character did not automatically improve. The result of the interview with some lecturers revealed that many students in the three universities leave obligatory prayers (sholat al-fardhu) and rarely read Holy Qur'an. A research on moral education in Hong Kong is highlight this statement. The use of moral discussion and moral lecture method contributed weakly on moral commitment of more than 1900 secondary students. The research also suggested importance of real-life moral education (Cheung \& Lee, 2010).

The cognitive tendency in teaching-learning activities of PAI in those universities is worsened with youth's social life in cities where universities locate. Many university students practice hedonism lifestyle, such as hanging out in a café, drinking alcohol, enjoying erotic dance, and having premarital sex (Farida, 2020; Wijayanto, 2003; Zulkifli, 2016). The involvement of university students in premarital sex is motivated by their reproductive organs' maturity and their previous experiences (Nugroho \& Afiyanti, 2019). Other aspects affected student sexual activities are exposure to porn videos of the internet or social media, social milieu, peer relationship, and parent control (Farida, 2020). Those two conditions hamper Islamic Education course to realize its strategic objective. According to Indonesian government rule, Islamic Education in a public university is responsible for developing students' faith and character to become a good Muslim with noble character. In this regulation about Religion Education and the Religiosity Education No. 55 of 2007 Chapter II Article 2 page 3 mentioned that "religion education has functioned in shaping the Indonesian individual that has a strong faith and piety upon the One Almighty God, also has the noble attitude and can keep the peace 
and order of the relationship among the same and different fellow of religions". Therefore, it is essential for religious education for living the nation that the government set the religion education (including Islamic Education) as mandatory subjects in elementary school to universities.

In perspective of Lickona's theory of character education, the cognitive tendency in teaching Islamic Education is categorized as moral knowing in character education (Lickona, 2009). It is only one aspect of character education that should be completed with the next two aspects: moral feeling and moral action. In this theory, Islamic education's objective cannot be realized if teaching-learning activities of PAI merely focus on knowing the good. Lecturers of Islamic Education must teach students desiring and loving the good and doing the good. If teaching-learning activities of Islamic Education have focused on these three aspects of character education, according to Lickona's theory, Islamic Education will successfully create a Muslim with noble character.

Considering the problems in teaching Islamic Education and the program of strengthening character education by government (Koesoema et al., 2017), it is essential to create innovation in teaching PAI in university to improve student character. Creating a model of teaching which focusing on improving students' character is innovation to solve the problems. The model of teaching is chosen because it guides a learning process to reach a learning objective. It consists of learning steps or syntax, social system, reaction, supporting system, indirect learning impact, and evaluation (Joyce, 1980). Such components facilitate lecturers to implement learning activities easier. Galvanised by Lickona's proposal, this study provides a teaching model designed to develop moral knowing, moral feeling and moral action of students. The model is named Participatory Observation.

Strategy or model for developing character education is an interesting subject. Many research types on the teaching model of religion education to develop student character are mainly classroom activities. Jumarudin et al developed the teaching model to internalize the religious-humanist values in primary education students through all the subjects (Jumarudin dkk., 2014). In other research, Hanifudin developed a teaching model of Islam Education based on Multiple Intelligence for Junior High School to create harmonious and equilibrium character, attitude, and good personality (Muhid et. al., 2019). At the university level, Sultoni developed model of teaching of Islam Education based on spiritual and emotional intelligence to improve students' character (Sultoni, 2018). All the models of teaching are implemented in classrooms.

For the teaching model of Islam Education practiced out of classrooms, a preliminary study by Nasih and Sultoni named "Participatory Observation" is a few types (Sultoni, 2018). This research is the next step of the preliminary study. This study aims to examine the effectiveness of "Participatory Observation" in improving students' characters and how students accept toward the teaching model.

\section{METHOD}

The research used mixed-method, quantitative, and qualitative. The design of the research is pre-experiment with pretest and post-test one shoot case study. The research steps begin with a pre-test using a gratitude and empathy questionnaire to measure students' spiritual and social character, followed by implementing the teaching model. At this step, students are asked to do social service in their community consisting of seven activities: orientation, finding a learning partner, initial observation, participatory observation, appreciation, report arrangement, and presentation and reflection. The last, students fill gratitude and empathy questionnaires and reflection forms.

The research participants are 125 students of Universitas Negeri Malang (UM), Universitas Jambi (UNJA), and Universitas Negeri Manado (UNEMA), who are chosen 
randomly. Data collection used gratitude and empathy questionnaires and reflection forms. The questionnaires are aimed to measure the gratitude of students (spiritual) and empathy of students (social); meanwhile, the reflection forms ask students to write down their reflection, action plan, and impression toward a model of teaching. The gratitude questionnaire is adapted from The Gratitude Questionnaire (GQ-6) by McCullough M., E. (2013), and the empathy questionnaire is adapted from Toronto Empathy Questionnaire. Having been tested using factor exploratory, the gratitude questionnaire got a validity score of 0.633 , and the empathy questionnaire was around 0.702. Meanwhile, the reliability test using Alpha Cronbach got a result of 0.708 for the gratitude questionnaire and 0.670 for the empathy questionnaire. All the scores were categorized high since the score of more than 0.5 , which are considerably high.

A paired T-test is chosen to determine whether the post-test score rise significantly compared to the pre-test score to analyse quantitative data from the questionnaires. Meanwhile, descriptive-qualitative analysis is used to formulate students' reflection and response to the model of teaching. Data of students' reflection were classified according to three aspects: gratitude, empathy, and another kind of character. Meanwhile, students' responses were categorized into two aspects: impression toward the teaching model and opinion toward the continuity of the teaching model.

\section{RESULTS AND DISSCUSSION}

The experiment did three times, in Universitas Negeri Malang, Universitas Jambi, and Universitas Negeri Manado. The pre-test and post-test scores in three universities are potrayed in the descriptive statistic in Table 1.

Table 1. Result of Experiment

\begin{tabular}{|c|c|c|c|c|c|c|}
\hline \multirow{2}{*}{ Descriptive Statistic } & \multicolumn{2}{|c|}{$\begin{array}{c}\text { Experiment 1: } \\
\text { UM }\end{array}$} & \multicolumn{2}{|c|}{$\begin{array}{c}\text { Experiment 2: } \\
\text { Unja }\end{array}$} & \multicolumn{2}{|c|}{$\begin{array}{c}\text { Experiment 3: } \\
\text { Unema }\end{array}$} \\
\hline & Pretest & Posttest & Pretest & Posttest & Pretest & Posttest \\
\hline Number of samples $(\mathrm{N})$ & 51 & 51 & 54 & 54 & 20 & 20 \\
\hline Minimum score & 39 & 49 & 39 & 48 & 39 & 50 \\
\hline Maximum score & 61 & 66 & 61 & 66 & 61 & 66 \\
\hline Mean & 52,05 & 56,85 & 45,3 & 50,05 & 50,56 & 56,7 \\
\hline Deviation standard & 5,60 & 3,99 & 6,20 & 5,45 & 3,52 & 4,70 \\
\hline
\end{tabular}

The result of the experiment, then, is tested its normality using the ormula KolmogorovSmirnov to determine the type of appropriate test. If the significance value ( $p$-value) more than alpha is $5 \%$, it means the data is distributed normally. Table 2 shows the result of the normality test.

Table 2. Result of Data Normality Test

\begin{tabular}{lllccc}
\hline \multicolumn{1}{c}{ Variable } & Data type & $\mathrm{N}$ & Kolmogorov-Smirnov $\mathrm{Z}$ & Sig. & Meaning \\
\hline \multirow{2}{*}{$\begin{array}{l}\text { Experiment 1: } \\
\text { UM }\end{array}$} & Pretest & 51 & 0,536 & 0,936 & Distributed normally \\
\cline { 2 - 6 } & Posttest & 51 & 0,655 & 0,785 & Distributed normally \\
\hline $\begin{array}{l}\text { Experiment 2: } \\
\text { Unja }\end{array}$ & Pretest & 54 & 0,547 & 0,926 & Distributed normally \\
\cline { 2 - 6 } $\begin{array}{l}\text { Experiment 3: } \\
\text { Unema }\end{array}$ & Posttest & 54 & 0,756 & 0,617 & Distributed normally \\
\cline { 2 - 6 } & Pretes & 20 & 0,720 & 0,678 & Distributed normally \\
\hline
\end{tabular}


Since the data normality test shows that data distribution is normal, a paired T-test is chosen to determine whether a mean score of pre-test differs from a post-test score. The formula is if $t_{\text {score }}$ greater than $t_{\text {table }}$ or value of significance (p-value) less than alpha $5 \%$, there is a statistically significant difference between pre-test and post-test score. Below is table 3 , which are described as the result of the paired T-test.

Table 3. Result of Paired t-test

\begin{tabular}{|c|c|c|c|c|c|c|c|}
\hline Variable & & $\mathrm{N}$ & Mean & $t_{\text {score }}$ & $D f$ & Sig. & Meaning \\
\hline \multirow{2}{*}{ Experiment 1: UM } & Pretest & 51 & 52,05 & \multirow{2}{*}{6,798} & \multirow{2}{*}{50} & \multirow{2}{*}{0,000} & \multirow{2}{*}{ Differ significantly } \\
\hline & Posttest & 51 & 56,85 & & & & \\
\hline \multirow{2}{*}{ Experiment 2: Unja } & Pretest & 54 & 45.3 & \multirow{2}{*}{5,991} & \multirow{2}{*}{53} & \multirow{2}{*}{0,000} & \multirow{2}{*}{ Differ significantly } \\
\hline & Posttest & 54 & 50,05 & & & & \\
\hline \multirow{2}{*}{ Experiment 3: Unema } & Pretest & 20 & 50,56 & \multirow{2}{*}{6,424} & \multirow{2}{*}{19} & \multirow{2}{*}{0,000} & \multirow{2}{*}{ Differ significantly } \\
\hline & Posttest & 20 & 56,7 & & & & \\
\hline
\end{tabular}

Based on the data (Table 3), it can be inferred that experiment in UM gets $t_{\text {score }} 6,798$ with significance 0,000 , and $t_{\text {table }}$ at free degree 50 and real degree 0,05 is 2,032. By comparing $t_{\text {score }}>$ $t_{\text {table }}$ or significance $<0,05$, there is a significant difference between pretest mean score to posttest mean score. Thus, it can be interpreted that the model of teaching can improve students' characters.

A similar result can be found in the experiment in UNJA, in which $t_{\text {score }}$ is 5,991 with significance 0,000, and $t_{\text {table }}$ at free degree 53 and real degree 0,05 is 2,046, and in UNEMA, the experiment got $\mathrm{t}_{\text {score }} 6,424$ with significance 0,000 , and $t_{\text {table }}$ at free degree 19 and real degree 0,05 is 2,054 . In comparison, $t_{\text {score }}>t_{\text {table }}$ or significance $<0,05$. It means that the post-test's mean score is significantly different from the pre-test. That is to say, the model of teaching participatory observation can improve the spiritual and social character of students.

The description of students' attitude supports a paired T-test after implementing the teaching model of participatory observation. The description shows that all students learn good characters such as patience, empathy, gratitude, respect, hard work, and parsimony. Some of the students' reflections are written in the following table.

Table 4. Examples of Students' Reflection

\begin{tabular}{|c|c|c|}
\hline Number & Students' expression & Aspects \\
\hline 1 & I thank more to God for His giving & \multirow[t]{3}{*}{ Gratitute to God } \\
\hline 2 & I learn that I should be more grateful on God's mercy & \\
\hline 3 & I should thank to God because of not every people as lucky as me & \\
\hline 4 & Now, I care more about people & \multirow{3}{*}{$\begin{array}{l}\text { Empathy to other } \\
\text { people }\end{array}$} \\
\hline 5 & I can control myself to manage money and time well & \\
\hline 6 & I am motivated to share money to other people & \\
\hline 7 & $\begin{array}{l}\text { Do not complain with your condition because other people have bigger } \\
\text { problem than you }\end{array}$ & \multirow{3}{*}{$\begin{array}{l}\text { Other moral values: } \\
\text { patience, hard work, } \\
\text { diligence }\end{array}$} \\
\hline 8 & I am inspired to work hard and not to surrender & \\
\hline 9 & I will be patient and diligent in coping problem of life & \\
\hline
\end{tabular}

The result of student reflection in table 4 informs that the Participatory Observation model improves students' character. The types of improved characters are limited to gratitude and empathy and another sort of character such as patience, diligence and hard work. All the character types increase on students after implementing participatory observation. 
In terms of students' responses toward the teaching model, their attitude is classified into two aspects: affection towards the model and the continuity of using the teaching model in Islamic Religion Education. Table 5 below showed the result of students' responses.

Table 5. Examples of Students' Response Toward the Teaching Model

\begin{tabular}{|c|c|c|c|}
\hline Number & Respon & Frequency & Aspect \\
\hline 1 & I like the model since.... & Seventy-two times & \multirow{2}{*}{$\begin{array}{l}\text { affection towards } \\
\text { teaching model }\end{array}$} \\
\hline 2 & I like the model very much because.... & Fifty-three times & \\
\hline 3 & $\begin{array}{l}\text { The model need to be implemented in Islamic } \\
\text { Education teaching because ... }\end{array}$ & Ninety-seven times & \multirow{2}{*}{$\begin{array}{l}\text { continuity of the } \\
\text { teaching model }\end{array}$} \\
\hline 4 & $\begin{array}{l}\text { It is very important for students to implement } \\
\text { this model because .... }\end{array}$ & Twenty eight times & \\
\hline
\end{tabular}

It can be inferred from Table 5 that all respondents give positive feedback toward the model of teaching. All students perceive the model of teaching nice to them for various reasons, with more than fifty-five percent of them said that the model was excellent. As a result, all respondents advise the model to be implemented in Islamic Education teaching.

The finding of this research provided evidence that the teaching model that confronted students with real-life and 'unlucky' condition is an interesting and effective way to improve students' social and religious characters. In line with this, improving character through direct experience from real life around students is fun and more heart-touching. In turn, this teaching model help students improving their character.

The result of this research reinforced that the use of adult as role models is an effective way for student character development, for example, professionals or parents (Berkowitz \& Bier, 2004; Park, 2004). In addition, the research finding also supported other research that an activity to integrate character to learning programs in university can be succeed in developing students moral (Brooks et. al., 2019).

This teaching model effectively in improves students' characters due to social interaction between students with "learning partners". As mentioned before, this teaching model required students to observe and participate in some day-to-day activities of "learning partners" with the low economy and social level. In social cognitive theory, moral actions are result of interaction between personal and social context (Bandura, 2002). Writing in a similar vein, Edinyang states that learning happened in a social context, namely social interaction, through observation, assimilation, and imitation (Dewey, 2001).

In particular, Okita explained that social interaction is urgent in learning activities because it helps students to build knowledge, do reflection, and revise reasoning processes (Okita, 2012). It means that when students interact with "learning partners", they learn and reflect on real-life that they see and experience, finally change the way they see life positively. They saw and perceived that other people must work harder and cope with difficulties to survive. The learning partners became a model of positive behaviour for students.

Other aspects contributing to the "Participatory Observation" teaching model's effectivity are student's activities in living the job of a learning partner and reflection. When students did the work of "learning partners", they experienced tiredness and difficulties in earning money, and they had to work hard to gain money. This new condition for students was then thought deeply through reflection. At this phase, students thoroughly compare their condition to learning partner situation. In this way, students learn noble values from learning partners, such as empathy or gratitude in themselves. The explanation is in line with the experiential learning theory that people learn from real experience, which they conceptualize and implement through reflective observation and active experimentation (Hanur \& Widayati, 2019). The finding that experience is one of the best media of effective learning corroborates previous research in universities (Burch et. al., 2014; Coker et. al., 2017). 
In learning theory, student activities with learning partners are called learning by doing. Dewey highly appreciated such learning activities. He suggested that educational institutions teach students how to live in their society. As a result, educational institutions should build a close relationship with family and society, where students live and learn to be good society members (Dewey, 2001).

Another finding that respondents were pleased and enjoyed implementing the model of teaching "Participatory Observation" confirmed an extensive investigation by Burch et. al. (2014), that students perceived positively learning through experience. Compared to another teaching model, this research is same as the model of teaching Emotional and Spiritual Intelligence (ESI) Integratif in terms of students' positive responses for enjoyable effect. However, a similar effect does not exist in other models such as integrating moral values in subjects or courses (Sultoni, 2018; Yuniastuti, 2017).

Teaching "Participatory Observation" has some advantages compared to a similar teaching model, such as a value clarification technique or VCT (Awiria et. al., 2019). This model is implemented out of the classroom, not to lessen learning time in the classroom. This is important for lecturers of Islamic Education since the subject only 3 hours of meeting; thus, they differ in improving character. In VCT, the character is enhanced using the cognition process through value analysis. In the model of participatory observation, however, character improvement is gained through reflection on real situations using feeling and cognition.

\section{CONCLUSION}

The teaching model Participatory Observation experiments in three public universities were effectively employed in improving students' characters. The teaching model's effectiveness agrees with students' opinion that they all felt a positive change in good character. In terms of acceptance, all students perceived the teaching model as very pleased and useful. Therefore, it can be concluded that the teaching model of Participatory Observation can be used in teaching PAI. Based on the results of this study, educators of PAI should consider teaching methods that use 'unlucky' society members' condition as role models to educate character. In the future, it is interesting to assess this teaching model in Islamic universities and other levels of education, such as senior high school or junior high school.

\section{BIBLIOGRAPHY}

Awiria, A., Nadiroh, N., \& Akbar, M. (2019). The Diversity of the National Culture of Elementary School Students Using the Value Clarification Technique Learning Model. International Journal of Multicultural and Multireligious Understanding, 6(3), 915-923. https://doi.org/10.18415/ijmmu.v6i3.863

Bandura, A. (2002). Selective moral disengagement in the exercise of moral agency. Journal of moral education, 31(2), 101-119. https://doi.org/10.1080/0305724022014322

Berkowitz, M. W., \& Bier, M. C. (2004). Based Character Education. The Annals of the American Academy of Political and Social Science, 591(1), 72-85. https://doi.org/10.1177/0002716203260082

Brooks, E., Brant, J., \& Lamb, M. (2019). How Can Universities Cultivate Leaders of Character? Insights from a Leadership and Character Development Program at the University of Oxford. International Journal of Ethics Education, 4(2), 167-182. https://doi.org/10.1007/s40889-019-00075-x

Burch, G. F., Batchelor, J. H., Heller, N. A., Shaw, J., Kendall, W., \& Turner, B. (2014). Experiential Learning —What Do We Know? A Meta-Analysis of 40 Years of Research.

Cheung, C., \& Lee, T. (2010). Contributions of Moral Education Lectures and Moral Discussion in Hong Kong Secondary Schools. Social psychology of education, 13(4), 575-591. https://doi.org/ 10.1007/s11218-010-9127-x 
Coker, J. S., Heiser, E., Taylor, L., \& Book, C. (2017). Impacts of Experiential Learning Depth and Breadth on Student Outcomes. Journal of Experiential Education, 40(1), 5-23. https://doi.org/10.1177/1053825916678265

Dewey, J. (2001). Democracy and Education. Pennsylvania: The Pennsylvania State University. Edinyang.

Farida, F. (2020). Determinan Perilaku Seks Bebas pada Kalangan Mahasiswa/Mahasiswi di Tempat Kos-Kosan di Kota Makassar. JIKI Jurnal Ilmiah Kesehatan IQRA, 8(1), 53-68. https://doi.org/10.1234/jiki.v8i1.181

Hanur, B. S., \& Widayati, T. (2019). Character Building di Abad 12 Masehi: Kajian dan Analisis Pendidikan Akhlak dalam Kitab Ta'lim Muta'Alim. Journal of Childhood Education, 2(1), 22 31. https://doi.org/10.30736/jce.v2i1.37

Hidayat, K. (1999). Memetakan Kembali Struktur Keilmuan Islam dalam Fuaduddin dan Cik Hasan Bisri (ed.) Dinamika Pemikiran Islam di Perguruan Tinggi: Wacana tentang Pendidikan Agama Islam. Jakarta.

Joyce, B. and M. W. (1980). Models of Teaching (3rd Edition). Prentice Hall.

Jumarudin, J., Gafur, A., \& Suardiman, S. P. (2014). Pengembangan Model Pembelajaran Humanis Religius dalam Pendidikan Karakter di Sekolah Dasar. Jurnal Pembangunan Pendidikan: Fondasi dan Aplikeasi, 2(2). https://doi.org/10.21831/jppfa.v2i2.2623

Koesoema, D., Safrina, R., Yusuf, A., (2017). Modul Pelatihan Penguatan Pendidikan Karakter bagi Guru. Jakarta: Kemendikbud.

Lickona, T. (2009). Educating for Character: How Our Schools Can Teach Respect and Responsibility. Bantam.

Muhid, A., Hadi, M., Fanani, A., Arifin, A., \& Hanif, A. (2019). The Effect of Hate Speech Exposure on Religious Intolerance Among Indonesian Muslim Teenagers. 2019 Ahmad Dablan International Conference Series on Education \& Learning, Social Science \& Humanities (ADICS-ELSSH 2019).

Nugroho, R. M., \& Afiyanti, Y. (2019). Sexual Compulsivity among Indonesian College Students. Comprehensive child and adolescent nursing, 42(sup1), 38-46. https://doi.org/10.1080/24694193.2019.1577924

Okita S. Y. (2012) Social Interactions and Learning. In: Seel N.M. (eds) Encyclopedia of the Sciences of Learning. Springer, Boston, MA. https://doi.org/10.1007/978-1-4419-14286_1770

Park, N. (2004). Character strengths and positive youth development. The Annals of the American Academy of Political and Social Science, 591(1), 40-54. https://doi.org/10.1177/0002716203260079

Sultoni, A. (2018). Pengembangan model pembelajaran Pendidikan Agama Islam berbasis kecerdasan spiritual dan emosional untuk membina akblak mahasiswa di Universitas Negeri Malang $[\mathrm{PhD}$ Thesis]. UIN Sunan Ampel Surabaya.

Tim Penyusun Modul. (2017). Modul Pelatiban Penguatan Pendidikan Karakter bagi Guru. Jakarta: Kemendikbud.

Wijayanto, I. (2003). Sex in the "kost". Yogyakarta: Tinta.

Yuniastuti, Y. (2017). Pengintegrasian Nilai-Nilai Karakter dalam Pembelajaran PPKn. Disertasi dan Tesis Program Pascasarjana UM.

Zulkifli, A. R. (2016). Gaya Hidup Hedonisme di Kalangan Mahasiswa Penerima Beasiswa Kaltim Cemerlang 2014 di Fakultas Ilmu Sosial dan Ilmu Politik Universitas Mulawarman. Sosiatri-Sosiologi, 4(1), 72-85. https://doi.org/10.22219/jipt.v6i2.7142 